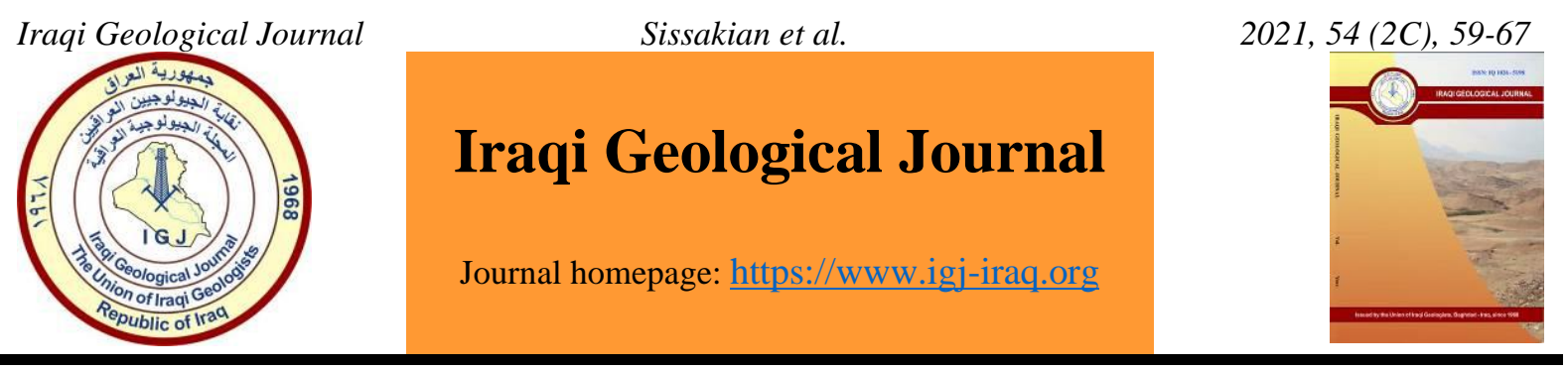

\title{
Suitability of the Carbonate Rocks of the Bekhme Formation for Cement Industry, Hareer Mountain, North Iraq, Kurdistan Region
}

\author{
Varoujan K. Sissakian', Ala A. Ghafur ${ }^{1}$, Fadhil. I. Ibrahem², Hawkar A. Abdulhaq1, Dalyia A. \\ Hamoodi $^{1}$ and Hassan O. Omer ${ }^{1}$ \\ 1 University of Kurdistan Heweler, Kurdistan Region, Iraq \\ 2 Mass Cement Company, Sulaimaniyah, Iraq \\ *Correspondence: f.khajeek@ukh.edu.krd
}

Received: 8 April 2021; Accepted: 10 May 2021; Published: 30 September 2021

\begin{abstract}
The main lithological composition of different formations in the Iraqi Kurdistan Region is the carbonate rocks; some of those rocks are suitable for cement production; such as Qamchuqa Bekhme, Sinjar, Pila Spi and Anah formations. However, the six existing cement plants in are using limestone beds, five of those plants are using limestone from the Sinjar Formation, and one plant is using limestone from the Anah Formation. Recently, performed research works confirmed that the limestone beds within the Qamchuqa, Bekhme and Pila Spi formations are very suitable for cement production. The current research work deals with studying the exposed limestone beds within the Bekhme Formation at Hareer Mountain in the central part of IKR to check their suitability for the cement industry. Accordingly, we collected 12 rock samples from a section within the Bekhme Formation at an almost constant sampling interval $(5 \mathrm{~m})$; however, for two samples the sampling interval was 6 and $8 \mathrm{~m}$ (sample No. 2 and 12, respectively). Each sample represents a channel sample for the concerned sampling interval to be representative for the thickness of the sampled interval. The total thickness of the sampled section is $64 \mathrm{~m}$ with a covered interval of $30 \mathrm{~m}$, totaling up to $94 \mathrm{~m}$. The collected 12 samples were prepared at the laboratory of the University of Kurdistan Hewler and were subjected to XRF test at Mass Cement Plant (Sulaimaniyah) to check the concentration of certain oxides that are used in the Iraqi Standard for cement production. The acquired concentrations of the main oxides $\left(\mathrm{CaO}, \mathrm{MgO}, \mathrm{Al}_{2} \mathrm{O}_{3}, \mathrm{Fe}_{2} \mathrm{O}_{3}, \mathrm{Na}_{2} \mathrm{O}, \mathrm{K}_{2} \mathrm{O}, \mathrm{SO}_{3}\right)$, and $\mathrm{Cl}$ and L.O.I. at each sample were changed to weighted averages and the results were compared with the Iraqi standards for cement industry. The result was the sampled rocks are excellent for cement production.
\end{abstract}

Keywords: Cement production; Bekhme Formation; Hareer anticline; Weighted average; Calcium carbonate

\section{Introduction}

Erbil Governorate, the capital of Iraqi Kurdistan Region (IKR) is witnessing great developments in the infrastructure; therefore, it needs large quantities of cement. However, there is only one cement plant in the governorate that is located $35 \mathrm{~km}$ south of Erbil city, whereas at Sulaymaniyah, there are five cement plants. This is attributed to the type of the exposed rocks within the existing geological formations in Erbil; as the geological conditions are concerned. It is worth to mention that the exposed rocks in Erbil are less studied as compared to those that are exposed in Sulaimaniyah. The sampled

DOI: 10.46717/igj.54.2C.6Ms-2021-09-25 
section is located in a deep cut valley that forms a wine glass form; along the southwestern flank of Hareer Mountain, about $9.5 \mathrm{~km}$ southeast of Hareer town (Fig. 1). It can be reached from Erbil city through a paved road (until $2 \mathrm{~km}$ south of the studied section) with a distance of about $50 \mathrm{~km}$. The section is also located near by the main road between Erbil and Duhok cities and farther more the main road to Zakho town and more northwest wards to Turkey. The section is limited by the following coordinates (from the base to the top): $36^{\circ} 28.471^{\prime} \mathrm{N}, 44^{\circ} 25.930^{\prime} \mathrm{E}$, and $36^{\circ} 28.444^{\prime} \mathrm{N}, 44^{\circ} 25.881^{\prime} \mathrm{E}$, respectively.

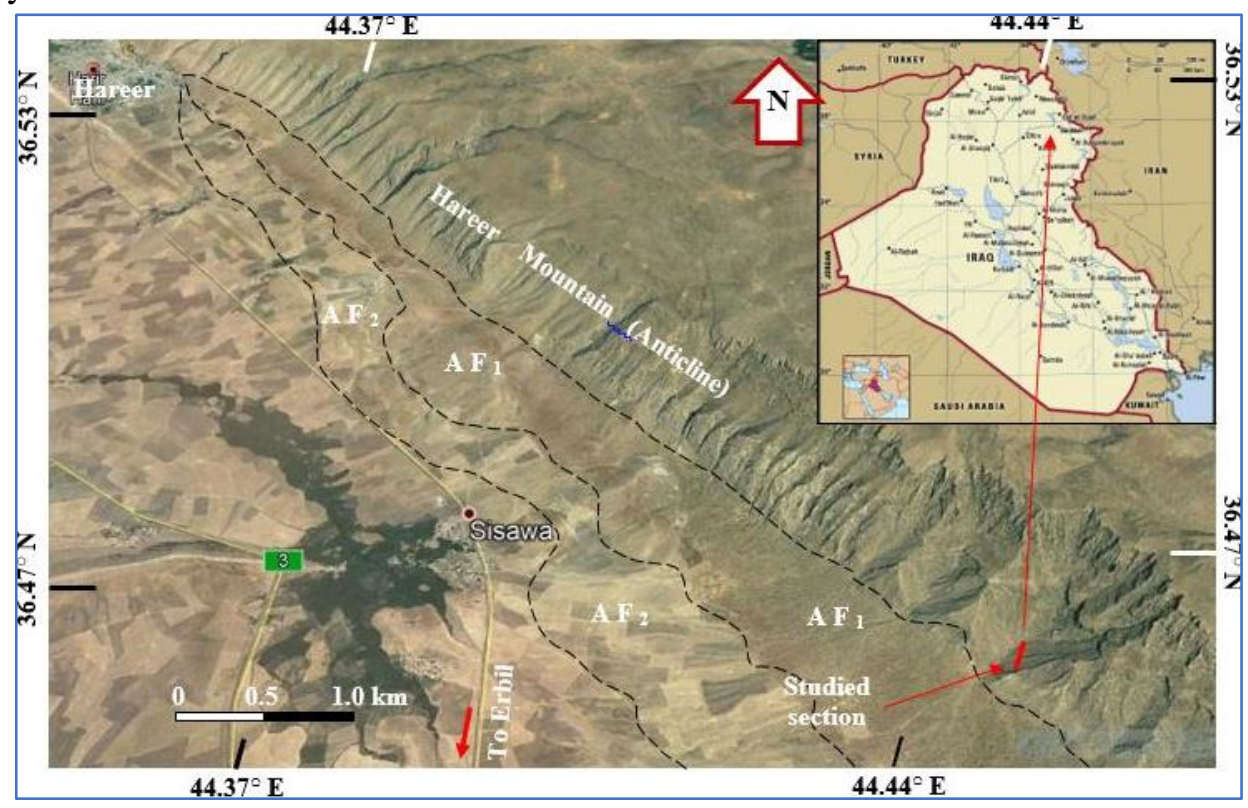

Fig. 1. Satellite image showing the location of the studied section. A $F_{1}$ and $A F_{2}$ represent two stages of alluvial fans

Since the last decade, many studies were performed to evaluate the carbonate rocks for different industrial uses, especially for cement production. We have briefed some of the performed studies hereinafter. Sissakian et al. (2019) studied the carbonate rocks that are exposed within the Pila Spi Formation in the southwestern limb of Permam anticline, near Al-Maseef. They reported about the presence of excellent quality and quantity of limestone. Ghafur et al. (2019) studied and evaluated the exposed beds of the Bekhme Formation at Galley Ali Beg gorge. They concluded that excellent deposit for cement industry exist at the studied location. Awadh and Al-Owaidi (2020), used the triangle methods for evaluating marl beds within the Euphrates Formation in central Iraq to be used in cement production. The Pila Spi Formation at Haibat Sultan Mountain; $17 \mathrm{~km}$ east of Koya city north Iraq includes limestone beds that are very suitable for the cement industry with huge quantities (Sissakian et al., 2020). The aim of this research work is to check the suitability of the carbonate rocks that are exposed within the Bekhme Formation for cement production. The large thickness of the exposed rocks, quarrying conditions and preexisting data encouraged us to select a relevant section within the Bekhme Formation at Hareer Mountain to perform the current research work.

\section{Geological Setting}

The geological setting of the studied section and near surrounding is briefed hereinafter including the following main topics based on Sissakian et al. (2014), Fouad (2015) and Sissakian and Al-Jiburi, (2014).

\subsection{Geomorphology}

The following main geomorphological units are developed along and near the studied section: 
- Structural Denudational Units: among them are the anticlinal ridges and flat irons, both are well developed in hard to very hard limestone beds of the Qamchuqa and Bekhme formations. Both units represent excellent locations for quarrying.

- Alluvial Fans, the sediments of the alluvial fans are well developed in two levels ( $\mathrm{A} \mathrm{F}_{1}$ and $\left.\mathrm{A} \mathrm{F}_{2}\right)$ and form a continuous belt along the southwestern limb of the Hareer anticline (Fig. 1). The fans consist of fine materials, especially $\mathrm{A}_{2}$ level, although rock fragments of different sizes occur on the top of the first level $\left(\mathrm{A} \mathrm{F}_{1}\right)$ of the alluvial fans. These sediments can be used as the second main raw material in the cement industry as clay.

\subsection{Stratigraphy}

The studied section is within the Bekhme Formation that is underlain by the Qamchuqa Formation both formations are described briefly hereinafter.

- Qamchuqa Formation (Lower Cretaceous), it consists of thickly bedded to massive carbonate rocks, and is exposed in some deeply cut valleys and along a fault scarp (Fig. 2). The formation is overlain by the Bekhme Formation, its exposed thickness near the studied section is about $100 \mathrm{~m}$.

- Bekhme Formation (Upper Cretaceous), it consists of well bedded to massive carbonate rocks, light grey and brown in colour, hard to very hard. The exposed thickness of the formation is about $220 \mathrm{~m}$. Regionally, the formation is overlain by the Shiranish Formation; however, in the studied section it is overlain by alluvial fan sediments (Fig. 1).

\subsection{Tectonics and Structural Geology}

Hareer anticline is located in the High Folded Zone, its southwestern limb forms the contact with Low Folded Zone (in the south). The High Folded Zone belongs to the Outer Platform of the Arabian Plate. The zone is also a part of the Zagros Fold-Thrust Belt that it is developed due to the collision of the Arabian and Iranian plates (Alavi, 2004 and Fouad, 2015). The exerted forces due to collision have developed tens of anticlines within the zone, some of those anticlines are faulted; among them is Hareer anticline. A long thrust fault runs along part of the northeastern limb of the anticline causing steep high fault scarps along which the Bekhme and Qamchuqa formations in the northeastern limb are thrusted over the Qamchuqa and Bekhme formations of the southwestern limb; causing the disappearance of the anticlinal axis (Figs. 2 and 3). These high cliffs can be utilized for quarrying of the exposed rocks along with them.

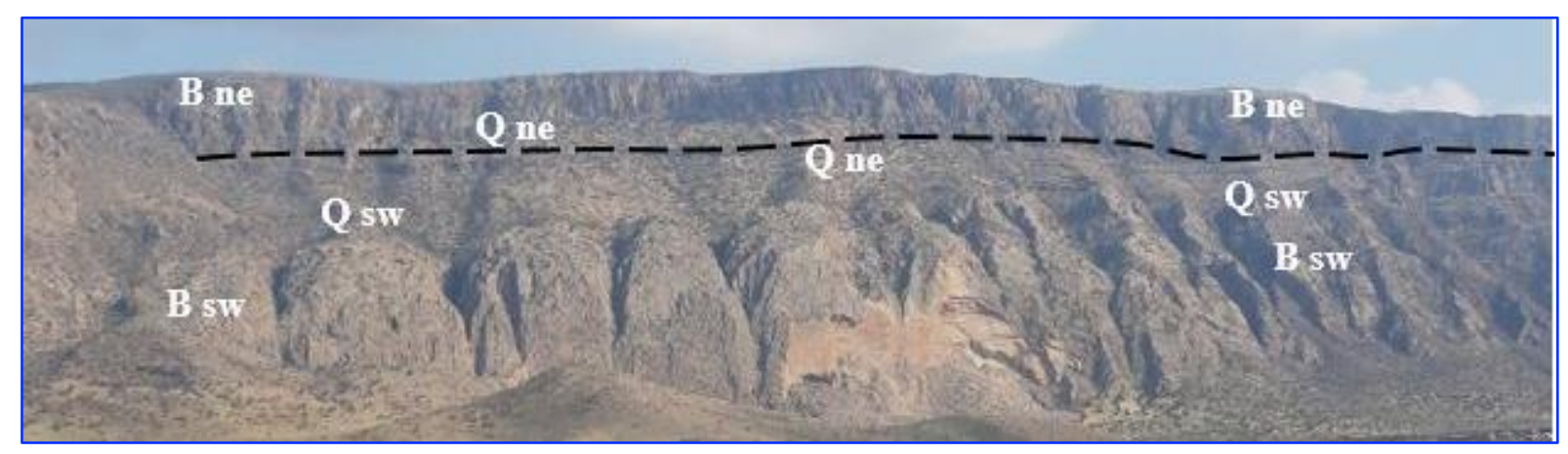

Fig. 2. Hareer anticline showing the long thrust fault (Dashed black line). Formations: $Q=Q$ amchuqa, $\mathrm{B}=$ Bekhme . Limbs: $\mathrm{ne}=$ Northeastern, $\mathrm{sw}=$ Southwestern. The studied section is along the last valley on the right side (Photo towards NNE) 


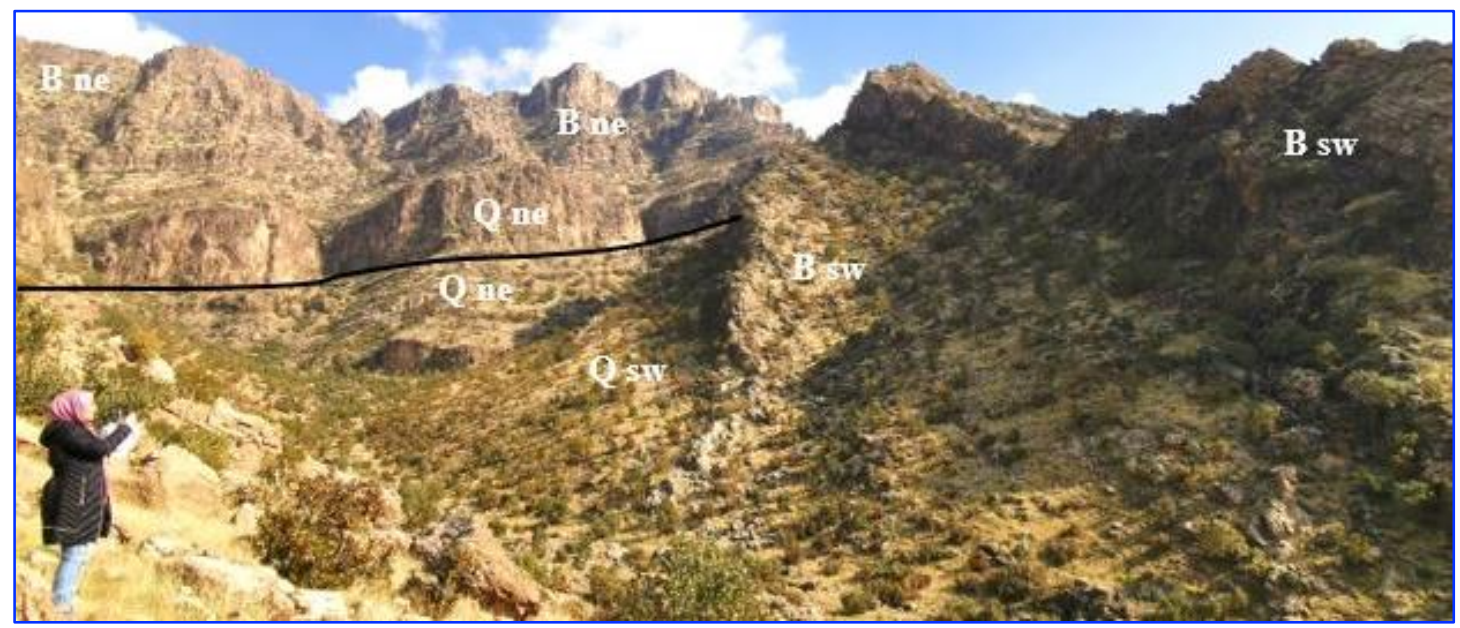

Fig. 3. Hareer anticline showing part of the long thrust fault (Black line). Formations: $Q=Q$ amchuqa, $\mathrm{B}=$ Bekhme . Limbs: ne= Northeastern, $\mathrm{sw}=$ Southwestern. The studied section is along the left side of the scene (Photo towards NNE)

\section{Materials and Methods}

In order to select a relevant section for sampling, we have used the authors experience in the field to indicate the exposures of the Bekhme Formation and the best quarrying conditions. The selected section was indicated in the field using the geological map and satellite image and Global Mapper. The exposed rocks along the selected section were sampled and described in the field and tested by $\mathrm{HCl}$ acid. The sampling interval was kept constant; 5 m, apart from sample No. 2 and No. 8 (Table 1). Each sample was collected in form of small chips representing the whole sampled sequence. Samples were kept in nylon sacks, numbered, and well documented (Table 1). Totally, 12 samples were collected representing $94 \mathrm{~m}$, among which $30 \mathrm{~m}$ of the covered slope by scree exist along the sampled section.

Table 1. Field description of the collected 12 samples

\begin{tabular}{|c|c|c|c|c|c|c|}
\hline $\begin{array}{c}\text { Sample } \\
\text { No. }\end{array}$ & Rock Name & Color & hardness & $\begin{array}{l}\text { Thick. } \\
\text { (m) }\end{array}$ & $\begin{array}{c}\text { Reaction with } \\
\text { HCl }\end{array}$ & Description \\
\hline 1 & Limestone & Light grey & Hard & 5 & High & Thickly bedded \\
\hline 2 & Limestone & Light brown & Very hard & 6 & Slight & Massive \\
\hline 3 & Limestone & Light grey & Hard & 5 & High & Thickly bedded \\
\hline \multicolumn{7}{|c|}{ Covered slope $(30 \mathrm{~m})$ by scree of large limestone blocks, most probably of limestone } \\
\hline 4 & Limestone & Light grey & Hard & 5 & High & Thickly bedded \\
\hline 5 & Limestone & Light grey & Hard & 5 & High & Thickly bedded \\
\hline 6 & Limestone & Light brown & Very hard & 5 & Slight & Massive \\
\hline 7 & Limestone & Light Grey & Very hard & 5 & Slight & Massive \\
\hline 8 & Limestone & Light Grey & Very hard & 5 & Slight & Massive \\
\hline 9 & Limestone & Grey & Very hard & 5 & Slight & Massive \\
\hline 10 & Limestone & Light Grey & Very hard & 5 & High & Thickly bedded \\
\hline 11 & Limestone & Light Grey & Very hard & 5 & High & Thickly bedded \\
\hline 12 & Limestone & Light Grey & Very hard & 8 & High & Thickly bedded \\
\hline \multicolumn{2}{|c|}{ Total thickness } & & & 94 & & \\
\hline
\end{tabular}

\subsection{Sample Preparation}

The collected 12 samples were grained to powder using electrical grinder. The powdered sample was mixed well to have a homogeneous representative sample. Then $10 \mathrm{gm}$ of the powdered sample was 
pressed in a special pellet. The pressed pellet was dried in an electrical oven for 2 hours. The prepared pellets were mounted in XRF equipment at the MASS Cement plant in Sulaimaniyah, Bazian, the Kurdistan Region, to indicate the required oxides $\left(\mathrm{CaO}, \mathrm{MgO}, \mathrm{Al}_{2} \mathrm{O}_{3}, \mathrm{Fe}_{2} \mathrm{O}_{3}, \mathrm{Na}_{2} \mathrm{O}, \mathrm{K}_{2} \mathrm{O}, \mathrm{SO}_{3}\right)$, and $\mathrm{Cl}$ and L.O.I. The acquired results are presented in Table 2.

\subsection{Weighted Averages}

The concentrations of all indicated oxides, Cl, and L.O.I. (Table 2) of each sample were changed to weighted percentage for industrial assessment purposes. This is because the sampling interval is not uniform; accordingly, for industrial assessment the weighted average should be calculated (IET, 2021).

Table 2. The chemical composition of the analyzed 12 samples using XRF

\begin{tabular}{ccccccccccc}
\hline $\begin{array}{c}\text { Sample } \\
\text { No. }\end{array}$ & $\mathbf{C a O}$ & $\mathbf{M g O}$ & $\begin{array}{c}\mathbf{S i O}_{2} \\
\boldsymbol{\%}\end{array}$ & $\begin{array}{c}\mathbf{F e}_{2} \mathbf{O}_{3} \\
\boldsymbol{\%}\end{array}$ & $\begin{array}{c}\mathbf{A l}_{2} \mathbf{O}_{3} \\
\boldsymbol{\%}\end{array}$ & $\begin{array}{c}\mathbf{N a}_{2} \mathbf{O} \\
\boldsymbol{\%}\end{array}$ & $\begin{array}{c}\mathbf{K}_{2} \mathbf{O} \\
\boldsymbol{\%}\end{array}$ & $\begin{array}{c}\mathbf{S O}_{3} \\
\boldsymbol{\%}\end{array}$ & $\begin{array}{c}\mathbf{C l} \\
\boldsymbol{\%}\end{array}$ & $\begin{array}{c}\text { L.O.I. } \\
\boldsymbol{\%}\end{array}$ \\
\hline 1 & 39.07 & 11.49 & 0.23 & 0.86 & 0.17 & 0.13 & 0.12 & 1.98 & 1.23 & 44.34 \\
2 & 32.82 & 12.86 & 0.11 & 0.86 & 0.17 & 0.97 & 0.78 & 1.30 & 2.4 & 46.05 \\
3 & 54.98 & 0.44 & 0.18 & 0.78 & 0.01 & 0.12 & 0.25 & 0.04 & 0.11 & 43.13 \\
4 & 54.89 & 0.39 & 0.17 & 0.76 & 0.02 & 1.45 & 1.21 & 0.05 & 0.34 & 40.59 \\
5 & 55.09 & 0.30 & 0.20 & 0.75 & N.D. & N.D. & N.D. & N.D. & 0.34 & 43.31 \\
6 & 54.99 & 0.31 & 0.19 & 0.76 & 0.01 & N.D. & N.D. & 0.29 & N.D. & 43.25 \\
7 & 55.27 & 0.21 & 0.19 & 0.76 & 0.01 & N.D. & N.D. & N.D. & N.D. & 43.46 \\
8 & 55.15 & 0.24 & 0.26 & 0.76 & 0.02 & N.D. & N.D. & N.D. & N.D. & 42.97 \\
9 & 55.10 & 0.22 & 0.13 & 0.78 & 0.02 & N.D. & N.D. & N.D. & 1.11 & 42.74 \\
10 & 55.42 & 0.18 & 0.28 & 0.75 & 0.02 & N.D. & N.D. & N.D. & 0.43 & 42.91 \\
11 & 55.14 & 0.19 & 0.14 & 0.77 & 0.02 & N.D. & N.D. & 0.10 & 0.54 & 42.90 \\
12 & 55.19 & 0.18 & 0.21 & 0.75 & 0.01 & N.D. & N.D. & 0.12 & 0.61 & 42.93 \\
\hline
\end{tabular}

The weighted percentage of each oxide in each sample is calculated by the following equation (IET, 2021)

$$
\text { Weighted Percentage }=\frac{\sum C 1+\mathrm{C} 2+\mathrm{C} 3+\mathrm{C} 4+\mathrm{Ci}}{\sum \mathrm{T} 1+\mathrm{T} 2+\mathrm{T} 3+\mathrm{T} 4+\mathrm{Ti}}
$$

Where $\mathrm{C}=$ the percentage of each oxide multiplied by the sample's thickness $(\mathrm{T})$, The weighted average is calculated as follows:

$$
\text { Weighted Percentage }=\frac{\sum \mathrm{W} 1+\mathrm{W} 2+\mathrm{W} 3+\mathrm{W} 4+\mathrm{Wi}}{\sum \mathrm{T} 1+\mathrm{T} 2+\mathrm{T} 3+\mathrm{T} 4+\mathrm{Ti}}
$$

Where $\mathrm{W}=$ the weighted percentage of each oxide multiplied by the sample's thickness $(\mathrm{T})$. The acquired results of the weighted averages of all tested oxides and other parameters are presented in Table 3. However, because samples No. 1 and 2 show low $\mathrm{CaO} \%$; therefore, we have considered two cases: A) for the 12 collected samples, and B) for the last ten samples (Table 3). The acquired results were compared with the Iraqi Standards (1992) for cement production (Table 4).

\section{Results}

The acquired results of the weighted averages from the collected and analyzed 12 samples (Table 3) were compared with the Iraqi Standards for the cement industry to indicate the suitability of the sampled limestone beds to be used in cement industry. Hereinafter are the results of the comparison for the cement industry. 
Table 3. The weighted averages of the oxides in the collected 12 samples

\begin{tabular}{|c|c|c|c|c|c|c|c|c|c|c|c|}
\hline \multirow[t]{2}{*}{$\begin{array}{c}\text { Sample } \\
\text { No. }\end{array}$} & \multirow[t]{2}{*}{$\begin{array}{c}\text { Thick. } \\
\text { (m) }\end{array}$} & \multicolumn{10}{|c|}{ Weighted averages (\%) } \\
\hline & & $\mathrm{CaO}$ & MgO & $\mathrm{SiO}_{2}$ & $\mathrm{Fe}_{2} \mathrm{O}_{3}$ & $\mathbf{A l}_{2} \mathbf{O}_{3}$ & $\mathrm{Na}_{2} \mathrm{O}$ & $\mathrm{K}_{2} \mathrm{O}$ & $\mathrm{SO}_{3}$ & $\mathbf{C l}$ & L.O.l. \\
\hline 1 & 5 & 195.35 & 57.45 & 1.15 & 4.30 & 0.85 & 0.65 & 0.60 & 9.90 & 6.15 & 221.70 \\
\hline 2 & 6 & 196.92 & 77.16 & 0.66 & 5.16 & 1.02 & 5.82 & 4.68 & 7.80 & 14.40 & 276.90 \\
\hline 3 & 5 & 274.90 & 2.20 & 0.90 & 3.90 & 0.05 & 0.60 & 1.25 & 0.20 & 0.55 & 215.65 \\
\hline 4 & 5 & 274.45 & 1.95 & 0.85 & 3.80 & 0.10 & 7.25 & 6.05 & 0.25 & 1.70 & 202.95 \\
\hline 5 & 5 & 275.45 & 1.50 & 1.00 & 3.75 & N.D. & N.D. & N.D. & N.D. & 1.70 & 216.55 \\
\hline 6 & 5 & 274.95 & 1.55 & 0.95 & 3.80 & 0.05 & N.D. & N.D. & 1.45 & N.D. & 216.25 \\
\hline 7 & 5 & 276.35 & 1.05 & 0.95 & 3.80 & 0.05 & N.D. & N.D. & N.D. & N.D. & 217.30 \\
\hline 8 & 5 & 275.75 & 1.20 & 1.30 & 3.80 & 0.10 & N.D. & N.D. & N.D. & N.D. & 214.85 \\
\hline 9 & 5 & 275.50 & 1.10 & 0.65 & 3.90 & 0.10 & N.D. & N.D. & N.D. & 5.55 & 213.70 \\
\hline 10 & 5 & 277.10 & 0.90 & 1.40 & 3.75 & 0.10 & N.D. & N.D. & N.D. & 2.15 & 214.55 \\
\hline 11 & 5 & 275.70 & 0.95 & 0.70 & 3.85 & 0.10 & N.D. & N.D. & N.D. & 2.70 & 214.50 \\
\hline 12 & 8 & 441.52 & 1.44 & 1.68 & 3.75 & 0.08 & N.D. & N.D. & 0.96 & 4.88 & 343.44 \\
\hline \multirow{2}{*}{ Total } & 64 & 3313.94 & 148.45 & 12.19 & 48.00 & 2.60 & 14.32 & 12.58 & 20.56 & 55.08 & 2768.29 \\
\hline & 53 & 2921.67 & 13.84 & 10.38 & 38.10 & 0.73 & 7.85 & 7.30 & 2.86 & 34.53 & 2269.69 \\
\hline \multirow{2}{*}{ Average } & A & 51.78 & 2.32 & 0.19 & 0.75 & 0.04 & 0,22 & 0.19 & 0.32 & 0.86 & 43.25 \\
\hline & B & 55.13 & 0.26 & 0.20 & 0.72 & 0.01 & 0.15 & 0.14 & 0.05 & 0.65 & 42.82 \\
\hline Average & A & \multicolumn{10}{|c|}{$51.78+43.25=95.03$} \\
\hline $\mathrm{CaCO}_{3}$ & B & \multicolumn{10}{|c|}{$55.13+42.82=97.95$} \\
\hline
\end{tabular}

Table 4. Iraqi Standards No.5 for cement production, 1984 (ISQC, 2016)

\begin{tabular}{lc}
\hline & Iraqi Standard \\
\hline $\mathrm{CaO}$ & $>45 \%$ \\
$\mathrm{MgO}$ & $<2 \%$ \\
$\mathrm{SO}_{3}$ & $<1 \%$ \\
$\mathrm{Cl}$ & $0.5-1.0 \%$ \\
$\mathrm{~K}_{2} \mathrm{O}+\mathrm{Na}_{2} \mathrm{O}$ & $0.05 \%$ \\
$\mathrm{Fe}_{2} \mathrm{O}_{3}$ & $<0.1 \% *$ \\
\hline
\end{tabular}

* For white cement only.

- Limestone: The acquired results of the weighted averages (Table 3) were compared with the Iraqi standards for cement industry (Table 4), the results are clearly indicating that in both used case (A and $\mathrm{B}$, Table 3), the whole samples succession at Hareer Mountain is suitable for cement industry. However, the $\mathrm{Fe}_{2} \mathrm{O}_{3}$ content is higher than $0.1 \%$ (Table 3); therefore, according to the Iraqi specifications cannot be used for white cement industry (Table 4).

- Clay Deposit: The second main raw material in the cement industry is clay, which may reach up to $40 \%$ of the raw mix; depending on the chemical composition of the used limestone. Huge clay deposit occurs within the alluvial fan sediments along the whole foot slopes of Hareer Mountain (Fig. 1). These deposits are rich in limestone fragments of different sizes, derived from Bekhme and Qamchuqa formations, especially the former that was sampled and excellent results were acquired (Table 3). The thickness of these deposits ranges from $1 \mathrm{~m}$ up to about 10 meters, but he coverage area (Fig. 1) is huge. Moreover, many exposed formations south and southwest of the sampled site; like the Gercus, Fatha, Injana, Mukdadiya Bai Hassan include huge thicknesses of claystone that have produced reddish brown clayey soil (Fig. 4), which can be used as the second main raw material.

- Gypsum Deposit: Gypsum is added to the clinker during grinding steps in the cement mill in the cement production. However, gypsum is not available neither near the sampled section nor nearby 
areas. The nearest site where gypsum is available is at the Aghjalar vicinity which is about $100 \mathrm{~km}$ SE of the sampled section (Sissakian et al., 2020); accordingly, forms one of the main negative points as the sampled area is concerned.

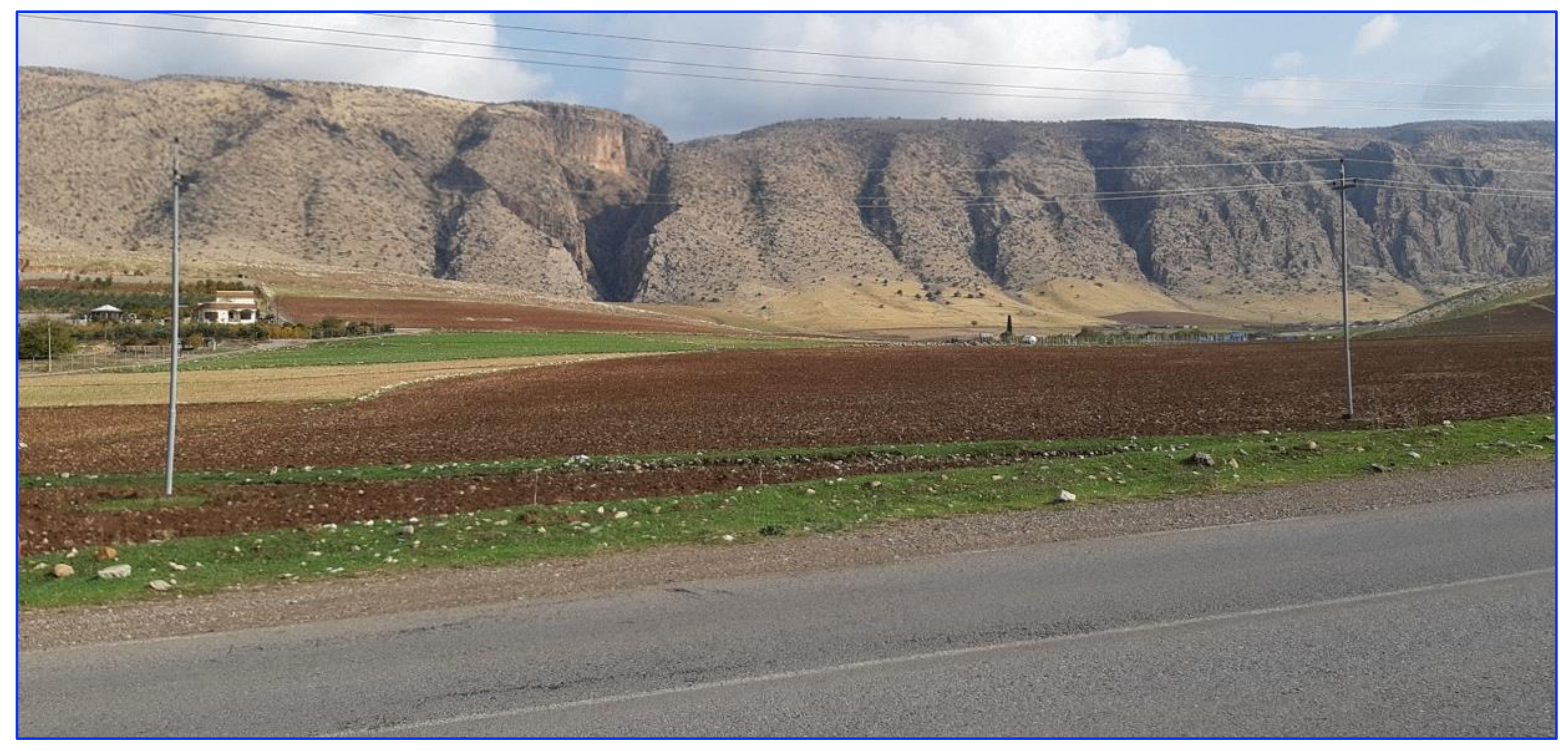

Fig. 4. General view of Hareer Mountain, note that the Bekhme Formation forms the carapace of the mountain; no overburden. Also note the presence of reddish-brown clayey soil. (Photo towards NE)

\section{Discussion}

Erbil, the capital of the Kurdistan Region is witnessing huge infrastructure development, yet there is only one cement plant within the governorate, whereas in Sulaimaniyah Governorate there are five cement plants with an average yearly production of 5 million tons per plant. Therefore, finding limestone beds, which are suitable for cement industry is a vital issue. Accordingly, we have selected a relevant site for sampling the exposed rocks and checking for their suitability for cement production. From the acquired results of the XRF test, it is clear that the exposed limestone beds of the Bekhme Formation within the sampled section at Hareer Mountain are excellent for cement industry (Tables 3 and 4). Moreover, the quarrying conditions at the sampling site and near surrounding are excellent as indicated from:

- There is no overburden (Figs. 2 and 4), not only at the sampling site but the whole Hareer Mountain,

- The presence of high cliffs (fault escarpment) and flat irons (Fig. 5) will facilitate the quarrying of the limestone beds,

- The clayey soil within the alluvial fans sediments (Fig. 1), and within many geological formations (Fig. 4) can be used as clay deposit for cement industry,

- The wide and flat areas along the foot hills of the Hareer Mountain (Figs. 1, 4 and 5) can be used as an excellent site for the cement plant, and. The absence of villages (apart from a small one) near the sampled site and near surrounding will decrease the negative environmental impact on the villagers. 


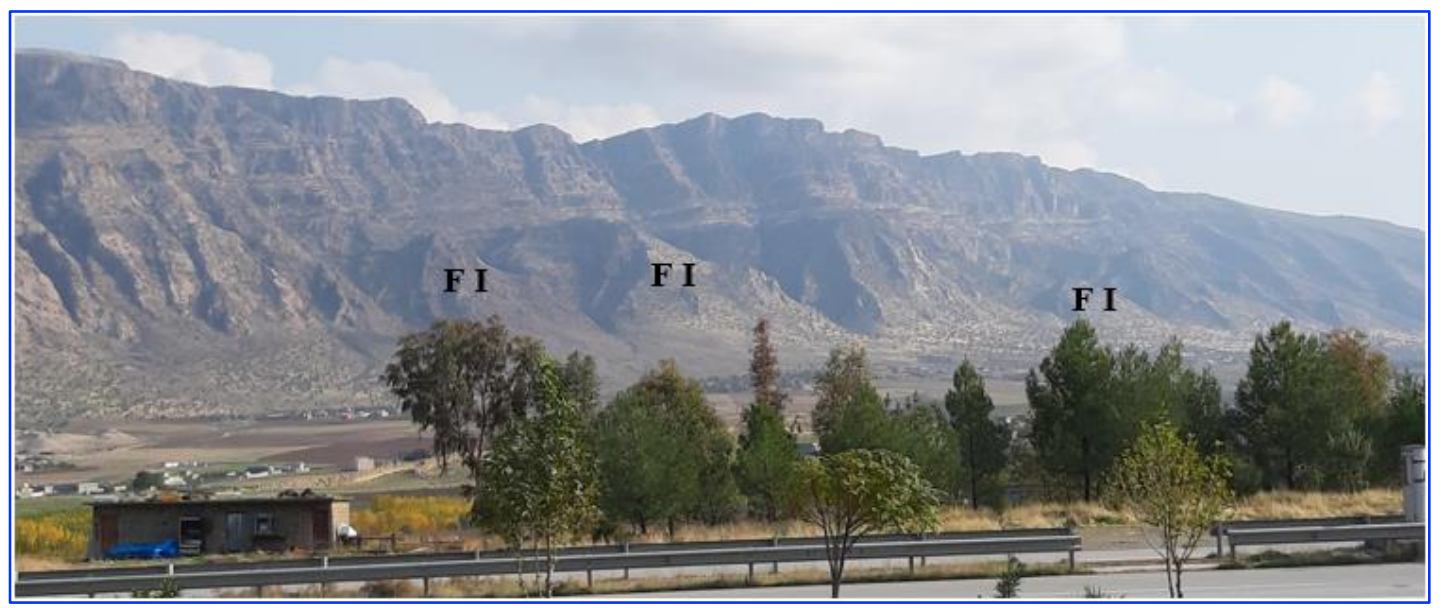

Fig. 5. General view of the Hareer Mountain, note developed Flat irons (FI) and high cliffs, which can serve as quarrying faces. (Photo towards NE)

The acquired weighted averages (Table 3) show that the concentration of the calcium carbonate $\left(\mathrm{CaCO}_{3}\right)$ within the sampled limestone beds, and in both calculated cases $(\mathrm{A}$ and $\mathrm{B})$ is very high $(95.03 \%$ and $97.95 \%$, respectively) indicating very pure calcium carbonate. Therefore, such pure calcium carbonate can be used in the drug industry (Congal, 2021). It is worth mentioning that the calcium carbonate is a dietary supplement that can be used when the amount of calcium taken in the diet is not enough. Calcium is also needed by the human's body for healthy bones, muscles, nervous system, and heart, it is also used as an antacid to relieve heartburn, acid indigestion, and upset stomach. Calcium carbonate with such purity also can be used for the treatment of cancer cases. This attributed to the gradual dissolution of calcium carbonate in the weak acidic microenvironment of cancer cells, the loaded doxorubicin can be released over the period of 14 days with $\mathrm{pH}$-responsive and sustained manner to specifically and significantly treat cancers (Render et al., 2016). Calcium carbonate is also one of the most popular mineral fillers used in many industries such as plastics, paint and rubber industries and is used in various applications from tires, wire cable, flexible PVC, pipes, flooring, coatings, adhesives etc. The main advantages of using the calcium carbonate include a high surface gloss or opacity. Additionally, when the particle size is carefully controlled, then $\mathrm{CaCO}_{3}$ helps to increase both impact strength and flexural modulus (stiffness) (Congal, 2021).

\section{Conclusions}

The weighted averages acquired from chemical analysis results for the 12 collected limestone samples from the Bekhme Formation at Hareer Mountain (anticline) showed pure limestone with $\mathrm{CaCO}_{3}$ attaining $97.95 \%$. The exposed rocks in the sampled section are excellent source raw material for cement industry. Moreover, the quarrying conditions are very favorable, the presence of clayey soil near by the sampled section and near surrounding is another favorable raw material for cement industry. The purity of the calcium carbonates is highly recommendable to be used in drug industry, besides other industrial uses such as paint, paper, rubber and plastic. However, the acquired results cannot be used for investment for any type of the mentioned industries, since these results indicate the studied section only.

\section{Acknowledgements}

The authors would like to pass their sincere thanks to the authorities at the University of Kurdistan Hewler for providing logistics during the field work for sample collections. Thanks also are extended to the authorities of MASS Cement Plant for subjecting the collected 12 limestone samples to XRF test. 
The authors are very grateful to the Editor in Chief Prof. Dr. Salih M. Awadh, the Secretary of Journal Mr. Samir R. Hijab. and the Technical Editors for their great efforts and valuable comments.

\section{References}

Alavi, M., 2004. Regional stratigraphy of the Zagros Fold, Thrust Belt of Iran and its proforeland evolution. American Journal Science, 304, 1-20.

Awadh, S. M., and Al-Owaidi, M. R., 2020. Application of triangles method for quantitative estimation of marl reserve in Euphrates Formation, middle of Iraq. Iraqi Geological Journal, 53 (2A), 35-49.

Congal, 2021. Calcium carbonate. plastic, rubber, paint (Last retrieved on 29 March 2021).

Ghafur, A.A., Sissakian, V.K. and Bapir, A.M., 2020. Industrial assessment of the rocks of the Bekhme Formation in Korek Mountain, Iraqi Kurdistan Region. Carbonates and Evaporates, 36 (1), 1-10.

IET (Indeed Educational Team), 2021. How to Calculate Weighted Average in 3 Steps (with Example). Internet data, last retrieved on 12 August, 2021.

Iraqi Standardization and Quality Control (2016). Iraqi Standards for cement Production, 1984. Last retrieved on 31 August. (In Arabic).

Render, D., Samuel, T., King, H., Vig, M., Jeelani,S., Jayachandra Babu, R. and Rangari, V., 2016. Biomaterialderived calcium carbonate nanoparticles for enteric drug delivery. Journal of Nanomaterials, 1- 8 .

Sissakian, V. K., 2018. The minerals wealth in the Kurdistan Region, Iraq. UKH Journal of Science and Engineering, 2(2), 23-36.

Sissakian, V. K., \& Al-Jiburi, B. S. 2014. Stratigraphy of the high folded zone. Iraqi Bulletin of Geology and Mining, (6), 73-161.

Sissakian, V.K., Kadhim, T.H., and Abdul Jab'bar, M.F., 2014. Geomorphology of the High Folded Zone. Iraqi Bulletin of Geology and Mining, 6, 7-56.

Sissakian, V.K., Hamoudi, D.A., Omer, H.O. and Niazi, S.A., 2019. Assessment of the carbonate rocks of the Pila Spi Formation for cement industry, in Permam Mountain, Erbil, Iraqi Kurdistan Region. UKH Journal of Science and Engineering, 3 (1),1-9.

Sissakian, V. K., Hamawandy, M. J., \& Ibrahim, R. K., 2020. Industrial Assessment of the Carbonate Rocks of the Pila Spi Formation at Haibat Sultan Mountain, Iraqi Kurdistan Region. ARO-the Scientific Journal of Koya University, 8(1), 24-30. 